\title{
On a Logical Reconstruction of the Kathavatthu
}

\author{
Andrew Schumann \\ University of Information Technology and Management in Rzeszow \\ Rzeszow, Poland \\ E-mail: andrew.schumann@gmail.com
}

\begin{abstract}
The Kathavatthu is one of the treatises of the Abhidhamma Pitaka of the Pali Canon. This treatise contains many different syllogisms - first of all, modus ponens and modus tollens. It is quite unique, because the same huge number of syllogisms involved into reasoning are contained only in the Milindapanha - another treatise of the Abhidhamma Pitaka. Usually, the authors of the Pali Canon do not appeal to pure syllogisms. In this paper, I show that syllogisms play rather a rhetoric role in the Kathavatthu. So, the author of the Kathavatthu had no excellent competence in logic because there are many sophisms among correct syllogisms and in the Kathavatthu there is no requirement to give examples in syllogisms. But the latter requirement is one of the principal ideas of the Indian logic to give examples for verifying premises. It is worth noting that in the Milindapanha there are no sophisms and there is a rule to exemplify premises.
\end{abstract}

Keywords-modus ponens; modus tollens; Kathavatthu; Milindapanha

\section{INTRODUCTION}

Among all the early Pāli texts containing different syllogisms, such as the Yamaka, the Kalahavivādasutta, and the Vijñānakāya, etc., there is a treatise, pakarana, written especially for the purpose of debates with non-Theravādins. It is a compendium of logical reasoning for different debates, called the Kathāvatthu, contained in the Abhidhamma Pitaka of the Pāli Canon. In this paper I will try to show that its author had no good competence in logic, although a lot of syllogisms of the Kathāvatthu are correct and really difficult. For another logical reconstruction of this text, please see [1] [2].

\section{EXAMPLES OF CORRECT SYLLOGISMS IN THE KATHĀVATTHU}

In this treatise we find many correct complex syllogisms, such as modus tollens: 'If $\mathrm{A}$ is $\mathrm{B}$, then $\mathrm{C}$ is $\mathrm{D}$. But $\mathrm{C}$ is not $\mathrm{D}$. Therefore, $\mathrm{A}$ is not B' [3]:

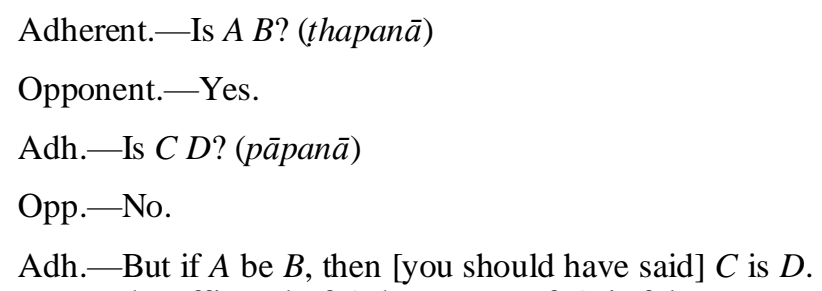
That $B$ can be affirmed of $A$, but not $D$ of $C$, is false. Hence your first answer is refuted. (ropanā).

$$
\begin{aligned}
& \text { Formally: } \\
& (A \Rightarrow B) \Rightarrow(C \Rightarrow D) ; \neg(C \Rightarrow D) \\
& \neg(A \Rightarrow B) .
\end{aligned}
$$

Another example of correct syllogism as a modification of modus tollens is logically formulated in the Kathāvatthu as follows: "If $\mathrm{D}$ be denied of $\mathrm{C}$, then $\mathrm{B}$ should have been denied of A. But you affirmed B of A. Therefore, that B can be affirmed of $\mathrm{A}$, but not $\mathrm{D}$ of $\mathrm{C}$, is wrong,' or in the simpler way: 'If $C$ is not $D$, then $A$ is not $B$. But A is B. Therefore $C$ is D' [3]. Formally:

$$
\neg(C \Rightarrow D) \Rightarrow \neg(A \Rightarrow B) ;(A \Rightarrow B)
$$

$$
(C \Rightarrow D) \text {. }
$$

\section{EXAMPLES OF INCORRECT SYLLOGISMS IN THE KATHĀVATTHU}

One of the most interesting evidences of the genuine role that logic plays in Theravāda Buddhism is contained in the first chapter of this text, called the Puggalakathā; the latter describes a debate between a Theravādin, who is a true Buddhist, and a Puggalavādin, another Buddhist who believes in the existence of a soul-like personal entity (puggalo). The point is that the reasoning involved in the debate from the opposite sides shows that the Theravādin as well as the Puggalavādin do not understand the subject of logic as ultimate inferring, although they use correct syllogisms sometimes.

Let us introduce some symbolic notations to make their debate more transparent:

$A$ is $B:=$ "“The person" (puggalo) is known in the sense of a real and ultimate fact.'

Puggalo upalabbhati saccikațthaparamatthenāti (Kathāvatthu 1).

$\mathrm{A}$ is $\mathrm{C}:=$ " "The person" is known in the same way as a real and ultimate fact is known.'

Yo saccikattho paramattho, tato so puggalo upalabbhati saccikațthaparamatthenāti? (Kathāvatthu 1).

Then their debate is taking place in the following manner: 
Theravādin.--Is $A B$ ?

Puggalavādin. - Yes.

Ther.-Is A C?

Pugg.-No.

Ther.-However, 'if $A$ is $B$, then $A$ is $C$.' Then that which you say here is wrong, because you state that ' $A$ is $B$ ' is true, but ' $A$ is $C$ ' is false. But if ' $A$ is $C$ ' is false, then ' $A$ is $B$ ' is false.

Symbolically:

$(A \Rightarrow B) \Rightarrow(A \Rightarrow C) ; \neg(A \Rightarrow C)$

$\neg(A \Rightarrow B)$.

It is an ad absurdum, because $\mathrm{A} \Rightarrow \mathrm{B}$ is true. It means that $\mathrm{A} \Rightarrow \mathrm{C}$ is true, too. Hence, we see that the final refutation is logically correct: 'If A is B, then A is C.' So, if ' $\mathrm{A}$ is $\mathrm{B}$ ' is true, 'A is $\mathrm{C}$ ' should be true, too. The Puggalavādin maintains that ' $\mathrm{A}$ is $\mathrm{C}$ ' is false. However, it means, as the Theravādin truly claims, that ' $\mathrm{A}$ is B' should be false, also. This syllogism is a classical modus tollens. Hence, the Theravādin has just refuted the Puggalavādin's opinion. But, let us look at the continuation of this dialogue:

Puggalavādin.--Is $A$ not $B$ ?

Theravādin.-Yes, it is not.

Pugg.--Is $A$ not $C$ ?

Ther.-No, it is.

Pugg.- However, 'if $A$ is not $B$, then $A$ is not $C$.' Then that which you say here is wrong, namely, that ' $A$ is not $B$ ' is true, but ' $A$ is not $C$ ' is false. But if ' $A$ is not $C$ ' is false, then ' $A$ is not $B$ ' is false, also. Thus, you are wrong.

Pugg.- - So, if ' $A$ is not $B$ ' is true, then ' $A$ is not $C$ ' is true. Now we, who admitted these propositions, do not consider ourselves to have been refuted. You say you have refuted us; anyway we are not well refuted.

Symbolically:

$\neg(A \Rightarrow B) \Rightarrow \neg(A \Rightarrow C) ; \neg \neg(A \Rightarrow C)$

$\neg \neg(A \Rightarrow B)$.

It is an ad absurdum, as well, because $A \Rightarrow C$ is true. From this it follows that $A \Rightarrow B$ is true, also. So, the Puggalavādin puts forward another implication, namely: 'if $A$ is not $B$, then $A$ is not $C^{\prime}[\neg(A \Rightarrow B) \Rightarrow \neg(A \Rightarrow C)]$. The Theravādin states that ' $A$ is not $C$ ' is false. From this it should follow according to the same modus tollens, as the Puggalavādin notes now, that ' $A$ is not $B$ ' is false. It means that the Puggalavādin has just refuted the Theravādin's opinion.

Thus, we have the following opposite sides:
Theravādin:

' $A$ is $B$ ' is false, ' $A$ is not

$B^{\prime}$ is true

' $A$ is $C$ ' is true, ' $A$ is not $C$ ' is false;

if ' $A$ is $B$ ', then ' $A$ is $C$.'

Puggalavādin:

' $A$ is $B$ ' is true, ' $A$ is not

$B^{\prime}$ ' is false;

' $A$ is $C$ ' is false, ' $A$ is not $C$ ' is true;

if ' $A$ is not $B$ ', then ' $A$ is not $C$.'

In order to apply the same modus tollens, the Theravādin appeals to the implication 'if $A$ is $B$, then $A$ is $C$ ' as the first premise of his syllogism and the Puggalavādin to the same implication, but with negations 'if $A$ is not $B$, then $A$ is not $C$ ' as the first premise of his syllogism. Who is right? Nobody! The problem is that the Theravādin as well as the Puggalavādin cannot agree on the first premises of their reasoning. Their dialogue looks like a logical paradox: the same propositions are true and false at the same time. One opposite side puts forward one implication to prove an own statement. Another side puts forward the same implication, but with negations to prove another statement. Such a dialogue can become interminable. Indeed, we face many modifications of the first dialogue in the Puggalakathā.

Formally:

Theravādin: if ' $A$ is $B$ ' is true by the Puggalavādin, then ' $A$ is $C$ ' should be true by the Puggalavādin also, but it is not.

Puggalavādin: $\quad$ if ' $A$ is not $B$ ' is true by the Theravādin, then ' $A$ is not $C$ ' should be true by the Theravādin also, but it is not.

The problem is that the author of the Kathavvatthu does not know how the implication $A \Rightarrow B$ can be verified. In the $n y \bar{a} y a$ and $y$ ogācāra logic, there are the following two ways of verifying the implication: (i) the (Aristotelian) way by showing that $B$ is a general (genus) for $A$; (ii) the (Stoic or Chryssipus) way by checking that $A$ is a cause for $B$. Hence, the sentence $A \Rightarrow B$ means, according to Nyāya and Yogācāra, that $A$ implies $B$ as a genus for $A$ or a causal consequence from $A$. This semantics for conditional sentences is unknown for the author of the Kathāvatthu. But without a verified implication, modus tollens plays just a rhetoric role.

Thus, on the one hand, the Theravādin as well as the Puggalavādin apply the formally correct modifications of modus tollens mentioned above, but, on the other hand, they do not give true inferences, but sophisms in fact, because the Theravādin uses the implication 'if $A$ is $B$ is true, then $A$ is $C$ is true' where the antecedent occurs he considers false and the Puggalavādin uses the implication 'if $A$ is not $B$ is true, then $A$ is not $C$ is true' where there is the antecedent he examines as false, too. However, we cannot infer from the false premises! This significant fact that modus tollens is a sophism because of the unverified implications is ignored [3] [4]. A complicated reasoning with many formulas does not mean immediately that its author is a logician. The matter is 
that this reasoning should be correct formally with, necessarily, correct verifications of all premises.

Let us introduce the following new notations:

$A$ is $B:=$ "“The person" (puggalo) is known in the sense of a real and ultimate fact.'

$C$ is $B:=$ 'Material quality ${ }^{1}$ is known in the sense of a real and ultimate fact.'

Then we have the following next dialogue:

Theravādin.-Is $A B$, and is $C B$ ?

Puggalavādin.-Yes.

Ther.-Is $C$ one thing and $A$ another?

Pugg. - No, that cannot truly be said.

Ther--However, if ' $A$ is $B$, and $C$ is $B$ ', then ' $A$ and $C$ are distinct things.' You are wrong to admit ' $A$ is $B$, and $C$ is $B$ ' and not ' $A$ and $C$ are distinct things.' If the latter is false, then the first is false.

$$
\begin{aligned}
& \text { Pugg.-Is } A B \text { ? } \\
& \text { Ther.-It is not. } \\
& \text { Pugg.-Is } C B \text { ? } \\
& \text { Ther.-Yes. } \\
& \text { Pugg.-Is } C \text { one thing and } A \text { another? } \\
& \text { Ther.-No, that cannot be truly said. }
\end{aligned}
$$

Pugg.- - If ' $C$ is $B$ ', then you should also have admitted that ' $A$ and $C$ are distinct things.' You are wrong in admitting the truth of ' $C$ is $B$ ' while you deny that of ' $A$ is $B$.' If $A$ and $C$ are not distinct things, then $A$ is $B$. Thus, your position is false.

Symbolically:

\section{Theravādin:}

Then they have used the same reasoning where for 'material quality' they have substituted the following new items: feeling; perception; coefficients (saìkhäras); consciousness; the organ of sight; the organ of hearing; the organ of smell; the organ of taste; the organ of touch; visible object; sound; odour; taste; tangible object; mind (sensis communis); cognizable object; eye as subjective element; sights as subjective element; visual cognition as subjective element; ear as subjective element; sounds as subjective element; auditory cognition as subjective element; nose as subjective element; odours as subjective element; olfactory cognition as subjective element; tongue as subjective element; tastes as subjective element; gustatory cognition as subjective element; body as subjective element; touches as subjective element; tactile cognition as subjective element; mind as subjective element; mind-cognizing as subjective element; cognizables as objective element; eye as controlling power; ear as controlling power; nose as controlling power; tongue as controlling power; body as controlling power; mind as controlling power; female sex as controlling power; male sex as controlling power; life as controlling power; pleasure as controlling power; pain as controlling power; joy as controlling power; grief as controlling power; hedonic indifference as controlling power; faith as controlling power; energy as controlling power; mindfulness as controlling power; samādhi as controlling power; understanding as controlling power; the thought: "I shall come to know the unknown" as controlling power; the coming to know as controlling power; the having known as controlling power.

$$
((A \Rightarrow B) \&(C \Rightarrow B)) \Rightarrow(A \vee C) ; \neg(A \vee C)
$$

$$
\neg(A \Rightarrow B) \& \neg(A \Rightarrow C) \text {. }
$$

Nevertheless, it is an incorrect form. The logically corrected form is thus:

$$
((A \Rightarrow B) \&(C \Rightarrow B)) \Rightarrow(A \vee C) ; \neg(A \vee C)
$$

$$
\neg(A \Rightarrow B) \vee \neg(A \Rightarrow C) .
$$

Puggalavādin:

$$
(\neg(A \Rightarrow B) \&(C \Rightarrow B)) \Rightarrow(A \vee C) ; \neg(A \vee C)
$$

$(A \Rightarrow B) \& \neg(C \Rightarrow B)$.

\section{I}

$\mathrm{t}$ is an incorrect form, also. The logically corrected form is as follows:

$$
(\neg(A \Rightarrow B) \&(C \Rightarrow B)) \Rightarrow(A \vee C) ; \neg(A \vee C)
$$

$$
(A \Rightarrow B) \vee \neg(C \Rightarrow B) .
$$

We deal here with two modifications of modus tollens again and in the same manner the Theravādin and the Puggalavādin demonstrate that they do not know how implication can be verified. So, they apply different implications to infer contradictions, since they do not have a procedure for verifying conditional propositions as well as other propositions at all. The Theravādin is based on the scheme: 'If $A$ is $B$ and $C$ is $B$, then $A$ and $C$ are distinct things.' If it is false that ' $A$ and $C$ are distinct things,' then it is false that ' $A$ is $B$ and $C$ is $B$.' The Puggalavādin offers the following scheme: 'If $A$ is not $B$ and $C$ is $B$, then $A$ and $C$ are distinct things.' If it is false that ' $A$ and $C$ are distinct things,' then it is false that ' $A$ is not $B$ and $C$ is $B$.'

The main problem of the author of the Kathavvatthu is that he does not know what the subject of logic is, but its subject is to infer automatically from premises which are verified as true sentences. In the Hindu terms, they do not know what pramāna (Sanskrit: प्रमाण, 'means of knowledge') is - how we can verify sentences. Notice that an appropriate Pāli word pamāna occurs several times in the Pâli Canon, but never in the meaning of 'means of knowledge'. The teaching on pramāna appeared in India much later than all the texts of the Pâli Canon were composed. In this teaching all the sources of the true knowledge are classified: pratyakșa (Sanskrit: प्रत्यक्षाय; Pāli: paccakkha; 'evidence,' 'first premises,' 'axioms' or 'underlying things',

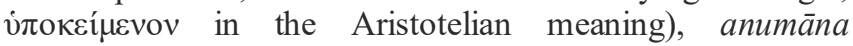
(Sanskrit: अनुमान; Pāli: anumāna; 'inference'), upamāna (Sanscrit: उपमान; Pāli: upamāna; 'comparison,' 'analogy'), 
arthāpatti (Sanskrit: अनुपलब्धि; 'postulation, derivation from circumstances' there is not this word in the Pāli Canon), anupalabdhi (Sanskrit: अभाव; 'non-perception, negative proof;' there is not this word in the Pâli Canon) and śabda (Sanskrit: शब्द; Pāli: sadda; 'word, testimony of past or present reliable experts'). In the European logic pramāna is a logical semantics and a logical epistemology, i.e. the rules how to ascribe meanings to logical propositions.

The Theravādin as well as the Puggalavādin are not familiar with any logical semantics. Therefore, they cannot agree on using premises. They do not know how to verify or falsify atomic propositions and how to build up true composite propositions on the basis of atomic ones. Although they know some correct syllogisms, they have no idea how these syllogisms can be verified or falsified.

Hence, the Kathāvatthu cannot be evaluated as a logical treatise in fact. There is not even a hint of pramāna in this text. Meanwhile, there are many sophisms presented as true inference rules, such as:

Theravādin.-Is the concept of soul derived from feeling?

Puggalavādin.-Yes.

Ther.-Is the concept of good soul derived from good feeling?

Pugg.- -Nay, that cannot truly be said [5].

Vedanạ̣ upādāya puggalassa paññattīti? Āmantā. Kusalaṃ vedanạ̣ upādāya kusalassa puggalassa paññattīiti? Na hevaṃ vattabbe ... pe ... (Kathāvatthu 192).

Ther.--If the concept of soul is derived from feeling, is the concept of bad soul derived from bad feeling?

Pugg. — Nay, that cannot truly be said [6].

Vedanaṃ upādāya puggalassa paññattīti? Āmantā. Akusalạ̣ vedanạ̣ upādāya akusalassa puggalassa paññattīti? Na hevạ̣ vattabbe ... pe ... (Kathāvatthu 193).

This text contains also a lot of references to authority (śabda of the nyāya) as an ultimate argument: 'it was not said by the Exalted One [A.Sch.-i.e. by the Buddha]' and 'it was said by the Exalted One.'

\section{CONCLUSION}

To sum up, the logical fragments of the Kathāvatthu are not connected to the pramanna doctrine as a whole and then, probably, they were transposed from disputes with some representatives of the Northern Buddhism (e.g. the Gandhāran Buddhism), because the logic is applied in the Kathāvatthu mechanically, without understanding a logical semantics or logical foundations. All syllogisms in the Kathāvatthu have only a rhetoric meaning and majority of them are sophisms in fact. In the meanwhile the Milindapañha, another treatise of the Pāli Canon demonstrates a good competence in logic, e.g. there are no sophisms and we face a requirement here to give examples for verifying statements [7] [8].

\section{ACKNOWLEDGEMENT}

I would like to express my deep gratitude to Prof. Andrey Paribok for discussing the topic of Indian philosophy and logic.

\section{REFERENCES}

[1] Jayatilleke K. N. Early Buddhist Theory of Knowledge. London: George Allen \& Unwin ltd, 1963, pp.305-368.

[2] Watanabe F. Philosophy and its Development in the Nikayas and Abhidhamma. Delhi, Varanasi, Patna: Motilal Banarsidass, 1983, pp.122-126, 154-174.

[3] Jayatilleke K. N. Early Buddhist Theory of Knowledge.

[4] Watanabe F. Philosophy and its Development in the Nikayas and Abhidhamma.

[5] Points of Controversy or Subjects of Discourse Being a Translation of the Kathā-vatthu. London: Published for the Pali Text Society by Humphrey Milford, Oxford University Press Warehouse, Amen Corner, 1915, pp. 33-34.

[6] Ibid.

[7] Milinda's Questions. Volumes 1-2. Translated by I. B. Horner. London: Luzac \& Company, Ltd., 1969.

[8] The Questions of King Milinda. Translated from the Pali by T. W. Rhys Davids. Oxford: the Clarendon Press, 1890 